\title{
Characterization of Silver Nanoparticles Obtained by a Green Route and Their Evaluation in the Bacterium of Pseudomonas aeruginosa
}

\author{
Juan Carlos Martínez Espinosa ${ }^{1, * \mathbb{D}}$, Raúl Carrera Cerritos ${ }^{1}$, \\ Maria Antonieta Ramírez Morales 2,3 (D), Karla Paola Sánchez Guerrero 1,4, \\ Rocio Alejandra Silva Contreras ${ }^{1}$ and Juan H. Macías ${ }^{5}$ \\ 1 Instituto Politécnico Nacional-UPIIG, Av. Mineral de Valenciana \#200, Fracc. Industrial Puerto Interior, \\ Silao de la Victoria, Guanajuato 36275, Mexico; rcarrerac@ipn.mx (R.C.C.); ksaarn@gmail.com (K.P.S.G.); \\ rsilvac@ipn.mx (R.A.S.C.) \\ 2 Skolkovo Institute of Science and Technology, 3 Nobel Street, Moscow 121205, Russia; \\ Maria.Ramirez@skoltech.ru \\ 3 NABICRON-Innovation Park AGROBIOTEG, Av. Camino Real de Guanajuato S/N, Ejido de Juarez, \\ Irapuato, Guanajuato 36630, Mexico \\ 4 NANOBIOTECH A.C.-Innovation Park AGROBIOTEG, Av. Camino Real de Guanajuato S/N, \\ Ejido de Juarez, Irapuato, Guanajuato 36630, Mexico \\ 5 Hospital Psiquiatico Fray Bernardino Alvarez, Av. San Buenaventura 2, Niño Jesús, Tlalpan, \\ 14000 Ciudad de México, CDMX, Mexico; humbertomacias@yahoo.com.mx \\ * Correspondence: jcmartineze@ipn.mx; Tel.: +52-5557-29-6000 (ext. 81378)
}

Received: 29 February 2020; Accepted: 3 April 2020; Published: 15 May 2020

\begin{abstract}
Metal nanoparticles are widely used in different areas such as biotechnology and biomedicine, for example in drug delivery, imaging and control of bacterial growth. The antimicrobial effect of silver has been identified as an alternative approach to the increasing bacterial resistance to antibiotics. Silver nanoparticles were synthesized by the green route using the Geranium extract as a reducing agent. The characterization was carried out by the techniques of UV-Vis spectrophotometry, transmission electron microscopy (TEM), high-resolution transmission electron microscopy (HRTEM), X-ray emitted photoelectron spectroscopy (XPS) and X-ray diffraction. Nanoparticle diameters between 15 and $50 \mathrm{~nm}$ were obtained and the interplanar spaces calculated from the electron diffraction pattern corresponding to a mixture of silver with $4 \mathrm{H}$ and FCC structures. To determine the minimum inhibitory concentration of silver nanoparticles (AgNPs) on the Pseudomonas aeruginosa bacteria (ATCC-27853), different concentrations of colloidal solution $0.36,0.18,0.09$ and $0.05 \mu \mathrm{g} / \mathrm{mL}$ were evaluated as a function of the incubation time, measuring the inhibition halo and colony forming unit (CFU) during 0, 2 and $4 \mathrm{~h}$ of incubation. The minimum inhibitory AgNPs concentration (MIC) is $0.36 \mu \mathrm{g} / \mathrm{mL}$ at $0 \mathrm{~h}$ while the concentration of $0.18 \mu \mathrm{g} / \mathrm{mL}$ presents a total inhibition of the bacterium after $2 \mathrm{~h}$. For the rest of the dilutions, gradual inhibitions as a function of time were observed. We evaluate the antibacterial effect of silver nanoparticles obtained by a green methodology in Pseudomonas aeruginosa bacteria. Finally, the colloidal nanoparticle solution can be an antibacterial alternative for different biomedical approaches.
\end{abstract}

Keywords: silver nanoparticles; green synthesis; antibacterial activity; Pseudomonas aeruginosa

\section{Introduction}

Recently, nanotechnology has revolutionized several areas of science in the search for new alternatives to improve the living conditions of humans, both in health and environmental fields [1-4]. 
In the field of materials science, nanoparticles are widely used for different applications, because their morphological properties, size, structure and distribution can be controlled and directed in specific applications [5-9]. However, these methodologies are a bit expensive and, therefore, it is complicated to have this type of equipment in conventional laboratories. Furthermore, the colloidal solutions generated are potentially dangerous for the environment due to the chemical compounds used as reducing agents [10-13]. Derived from the above, the application of ecological and biological methods is a viable synthesis alternative for the manufacture of nanomaterials, because they use microorganisms, plant biomass or plant extracts as reducing agents during chemical synthesis [14-16].

Previously, the use of plant extracts such as Aloevera, Crocus sativus, Datura stramonium, Ricinus communis, Olea europaea, Citrus medica Linn, and others has been reported [17-24], to synthesize copper, gold and zinc nanoparticles with diameters from 5 to $80 \mathrm{~nm}$ [25-30]. However, the most studied nanoparticles are silver, due to their lack of toxicity and better antibacterial properties.

AgNPs are applied in biomedicine for in vivo and in vitro studies of cytotoxicity [31,32], anti-inflammatory drug catalysts, and treatment of breast, gastric, and colon cancer [6,8,33-35]. Additionally, specifically using medicinal plant extracts, AgNPs have been shown to be effective in the treatment of diabetes mellitus and against bacteria such as E. coli, K. pneumoniae, S. aureus, $S$. typh $i$ and others $[9,21,22,36-38]$. The successful synthesis of AgNPs has been reported using garlic extract (Allium sativum), nopal (Opuntia sp) and eucalyptus (Eucalyptus chapmaniana) [39-41], as well as antimicrobial activity against multiple microorganisms, using banana peel extract [42].

In this paper, a green route for the synthesis of AgNPs is proposed using Geranium extract as a reducing agent. The obtained AgNPs have a diameter up to $50 \mathrm{~nm}$. We demonstrated their antibacterial activity against Pseudomonas aeruginosa (ATCC-27853) using different concentrations of the colloidal solution as a function of incubation time.

\section{Materials and Methods}

\subsection{Strain and Growth Culture}

Pseudomonas aeruginosa (ATCC-27853) was incubated in nutrient broth at $35{ }^{\circ} \mathrm{C}$ in a natural convection incubator (INB 500, Memmert, WI, USA) for $24 \mathrm{~h}$ until reaching an optical density equivalent to 0.5 on the McFarland scale.

\subsection{Extract Preparation}

Extract was prepared using fresh leaves of Geranium. Leaves were washed and mixed with distilled water up to boiling point for $5 \mathrm{~min}$. Finally, the solution was filtered using a vacuum Kitasato filter (Büchner funnel, Busch R5 RA 0010C vacuum pump, Munich, Germany) and refrigerated at $4{ }^{\circ} \mathrm{C}$.

\subsection{Synthesis of Silver Nanoparticles (AgNPs)}

Silver nanoparticle colloidal solution was synthesized by a green method, through the reduction of silver nitrate $\left(\mathrm{AgNO}_{3}\right) \mathrm{NC}-0846$ (Science company, Lakewood, $\left.\mathrm{CO}, \mathrm{USA}\right)$, using $90 \mathrm{~mL}$ at a concentration of $5 \mathrm{mM}$ mixed with $10 \mathrm{~mL}$ of Geranium extract. The reaction was carried out at $85^{\circ} \mathrm{C}$ for $2 \mathrm{~h}$.

\subsection{Nanoparticles Characterization}

To determine the initial concentration of the colloidal solutions of AgNPs, the samples were analyzed by an accredited external laboratory (Laquimia lab) of the Federal Commission for the Protection Against Sanitary Risks (COFEPRIS, https://www.gob.mx/cofepris/documentos/relacion-deterceros-autorizados) using the EPA 6020A analytical method with an inductively coupled plasma mass spectrometry system (ICP-MS). UV-Vis absorption spectra were measured by a spectrophotomer (NanoDrop 2000 c, Thermo Fisher Scientific, Wilmington, USA) in the wavelength range from 200 to $900 \mathrm{~nm}$ with a resolution of $1 \mathrm{~nm}$. Diameter of nanoparticles was determined by transmission electron microscopy, and $3 \mu \mathrm{L}$ of the colloidal solution was collected in a copper mesh grid coated with 
carbon substrate Ted Pella, using a transmission electron microscope (JEOL JEM-1010, Tokyo, Japan) at $80 \mathrm{kV}$. XRD measurement was recorded in a diffractometer from Rigaku using an X-source of $\mathrm{CuK} \alpha$, operated with a step size $2 \theta=0.01^{\circ}$ and a step time of $1 \mathrm{~s}$. HRTEM micrographs were taken with a JEM-2100 (JEOL, Tokyo, Japan) microscope, equipped with a LaB6 source operated from 80 to $200 \mathrm{kV}$. X-ray photoelectron spectroscopy (XPS) was carried out using a K-alpha spectrometer (Thermo Fischer Scientific, Wilmington, USA) with a monochromatic Al Karadiation (1486.6 eV) as an X-Ray source, and was micro-focused at the source to give a spot size on the sample of 400 microns in diameter. XPS assessment and high-resolution spectra were collected using analyzer pass energies of 120 and $40 \mathrm{eV}$, respectively. The samples remained in the pre-chamber for $15 \mathrm{~h}$ and later shifted to the analytical chamber with a base pressure of $1 \times 10^{-9}$ Torr.

\subsection{Evaluation of Antimicrobial Activity (Minimum Inhibitory Concentration MIC)}

P. aeruginosa was incubated at $35^{\circ} \mathrm{C}$ for $4 \mathrm{~h}$ in nutritious broth with AgNPs at concentrations of 0.36, 0.18, 0.09 and $0.05 \mu \mathrm{g} / \mathrm{mL}$ in a shaker incubator (ZHWY-200D, Mark Zhicheng, Shangai, China). A quantity of $100 \mu \mathrm{L}$ of each sample was added to nutritive (Nutrient Agar) agar plates during different incubation times $(0,2$, and $4 \mathrm{~h}$ ), distributing the sample on the plate with a Digralsky loop (Digralsky spreader). The plates were incubated at $35^{\circ} \mathrm{C}$ in a natural convection incubator for $24 \mathrm{~h}$ and then the CFU count was performed.

\subsection{Antibacterial Sensitivity}

Dilutions of silver nanoparticles were made in distilled water at concentrations of $0.36,0.18$, 0.09 and $0.05 \mu \mathrm{g} / \mathrm{mL}$. Sterile filter paper disks of approximately $5 \mathrm{~mm}$ in diameter with $1 \mu \mathrm{L}$ of each concentration were dispensed into a sterile Petri dish. Sterile swabs were used to inoculate Mueller Hinton Agar plates, immersing the tip of the latter in the culture of P. aeruginosa and passing the wet swab over the entire surface of the plate. Using sterile forceps, the dry disc was taken, placing it on the inoculated plate and pressing gently. Three discs were placed per plate and incubated at $35^{\circ} \mathrm{C}$ for $24 \mathrm{~h}$.

\section{Results and Discussion}

The synthesis of nanoparticles is considered a complex, expensive and contaminating process due to the use of chemicals and reagents, so it is convenient to use green synthesis, using plants to obtain extracts with high antioxidant capacity. The extract reacts with a silver nitrate solution, initiating the reduction of the metal ions and inducing the formation of the nucleation centers and, thus, forming the nanoparticles [23,29]. Once the reaction was initiated, samples were taken at 0, 30, 60, 120 and $180 \mathrm{~min}$ to monitor the changes in color solution that indicate the formation of the nanoparticles. Due to the excitation of plasmon surface vibrations in the metallic nanoparticles, it is possible to observe that the solution turns a brown color from $20 \mathrm{~min}$ after the start of the reaction kinetics $[43,44]$. The results obtained by the authorized external laboratory on the concentration of colloidal silver in a 1:1 ratio was $0.72 \times 10^{-3} \mathrm{mg} / \mathrm{mL}$, according to the ICP-MS analytical method applied.

In UV-Vis technique measurements, the absorption peak depends mainly on the morphology, structure and size of the particles that are obtained through some green or chemical synthesis methodology [45,46]. Using a sweep in the range of 200 to $900 \mathrm{~nm}$, the absorption peak was obtained at $435 \mathrm{~nm}$ (Figure 1A), which is very similar to those reported by different researchers. In the case of chemical synthesis methods, the absorption peak of AgNPs is within the range of 398-406 nm at $65^{\circ} \mathrm{C}$ using NaBH4 . In other research works, it has been reported that after $120 \mathrm{~min}$ of the reaction, the absorption peak is located at $434 \mathrm{~nm}$, when the extract of $M$. wightiana is used as a reducing agent for a synthesis methodology by the green route [47-49]. 


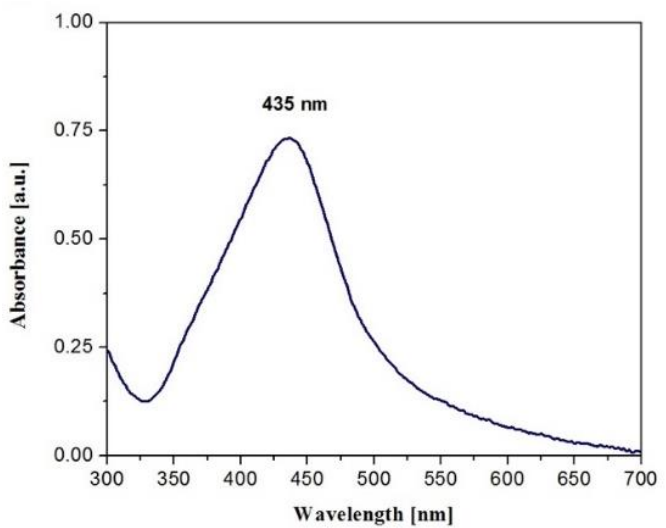

(A)

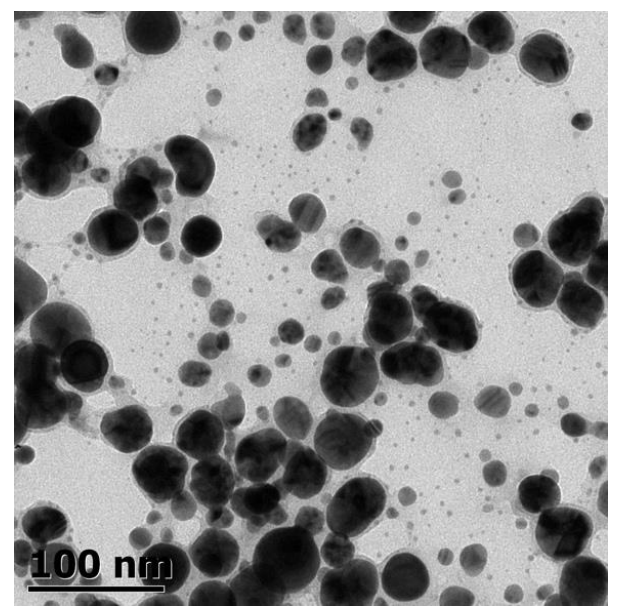

(C)

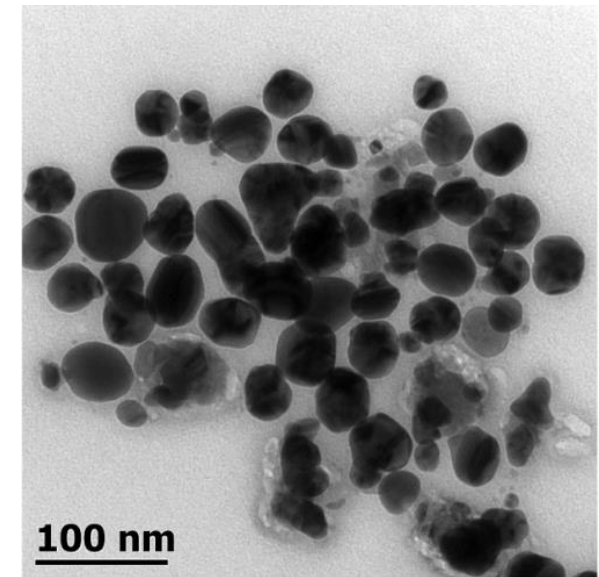

(B)

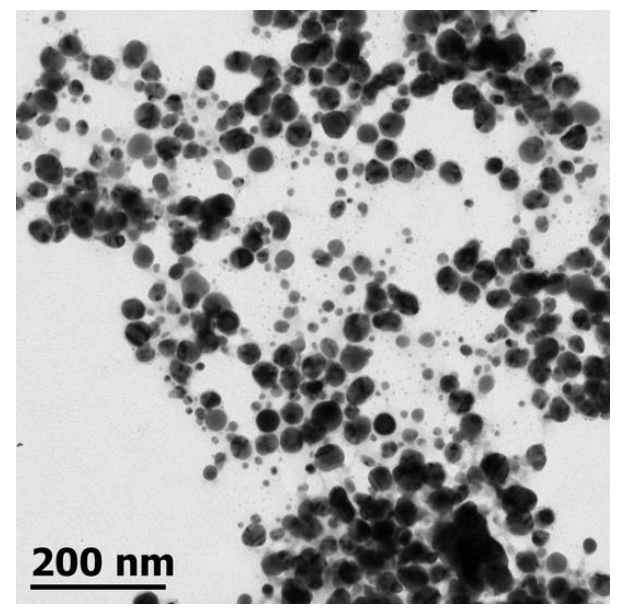

(D)

Figure 1. (A) UV-Vis extinction spectra of silver nanoparticles centered at $435 \mathrm{~nm}$. (B-D) Representative micrographs of AgNPs synthesized using Geranium extract at a constant temperature of $85^{\circ} \mathrm{C}$.

To document the morphological properties of the synthesized nanoparticles, transmission electron microscopy was performed. The average size of the nanoparticles obtained was from 15 to $50 \mathrm{~nm}$. Figure 1B-D shows a representative micrograph of the nanoparticles synthesized by the green route with a uniform spherical morphology.

Unlike chemical methods, the average size ranges between 10 and $20 \mathrm{~nm}$ [48], while for $M$. wightiana it is from 15-65 nm with irregular and polydisperse morphologies [47]. The difference in morphology and size distribution can be explained by the different mechanisms of nucleation and growth, which depend on multiple conditions, including temperature and time [50,51]. At higher temperatures, the induction period is accelerated, and in both the nucleation stages a greater number of particles are formed, but this is smaller compared to lower temperature conditions [52,53].

Figure 2 shows the XRD pattern of silver nanoparticles. Small diffraction peaks belonging to the trigonal structure of $\mathrm{AgNO}_{3}$ (COD entry No. 96-210-5348) and cubic- $\mathrm{Ag}_{2} \mathrm{O}$ (JCPDS No. 761396) revealed that the reduction reaction of Ag-precursor was incomplete. In addition, a FCC-Ag structure was identified with high peaks centered around $2 \theta=38.202,44.402,64.602,77.6$ and $81.758^{\circ}$, corresponding to (1 11 1), (2 0 0), (2 20 ), (3 11 1) and (2 2 2), respectively (JCPDS No. 040783). However, the experimental pattern slightly shifted towards higher angles compared to JCPDS card (blue lines). This was evidence of cell contraction of Ag nanoparticles with FCC structure. Interestingly, weak diffractions at $2 \theta=35.89$,

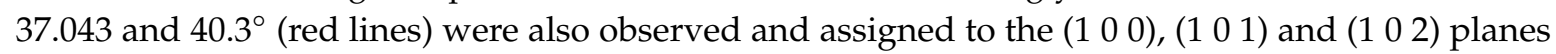
of the hexagonal silver $4 \mathrm{H}$ structure (ICDS No. 064707). This result was unexpected, as $4 \mathrm{H}$ phase is 
hardly ever reported in nanoparticle synthesis by green routes. In order to provide deeper knowledge of the crystal structure, HRTEM analyses were carried out for different nanoparticles of the sample.

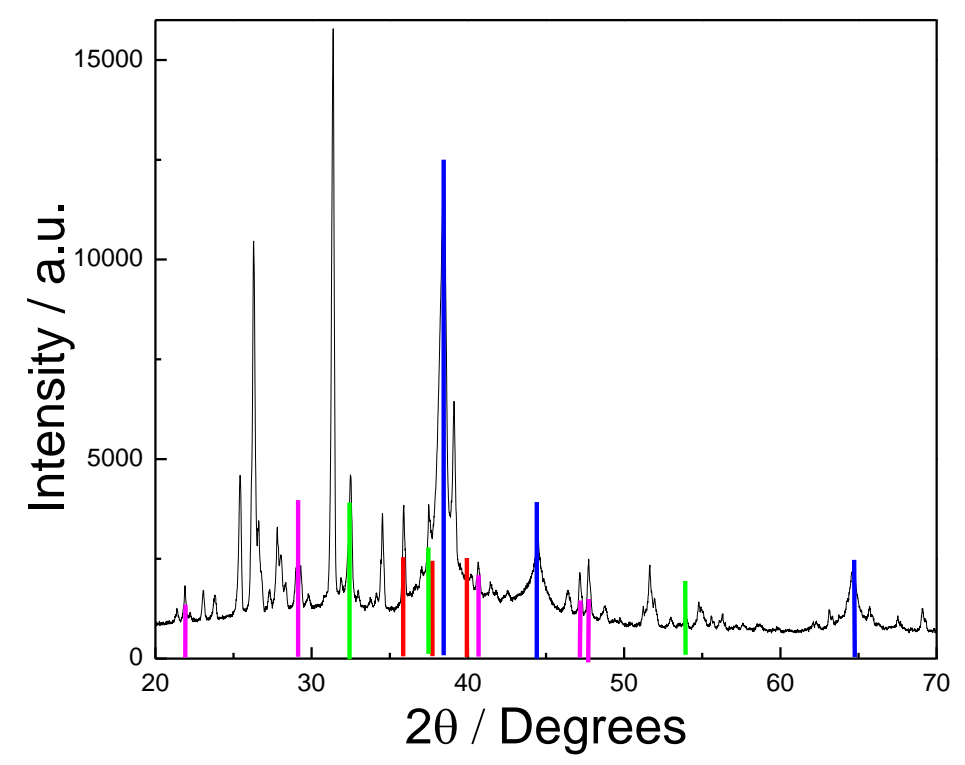

Figure 2. X-ray diffraction patterns of Ag nanoparticles synthesized with Geranium. Magenta, green, blue and red lines correspond to $\mathrm{AgNO}_{3}, \mathrm{Ag}_{2} \mathrm{O}, \mathrm{FCC} \mathrm{Ag}$, and hexagonal $4 \mathrm{H} \mathrm{Ag}$ structures respectively.

Figure 3A,B show an example of HRTEM and IFFT acquired in some Ag nanoparticles; the interplanar spaces calculated from the electron diffraction pattern correspond to $\left(\begin{array}{lll}1 & 0 & 1\end{array}\right),\left(\begin{array}{ll}1 & 0\end{array}\right)$ and (1 03 3) planes of a contracted hexagonal close-packed structure (HCP). This result was unexpected, but confirmed the XRD results already discussed, as a face-centered cubic structure (FCC) for metallic silver is typically found in synthesis reports of Ag nanoparticles [50-56]. However, recent studies have also reported the formation of HCP structures in silver thin films and nanoparticles obtained from chemical and green synthesis methods [57]. For instance, Chakraborty et al. [58] observed the presence of $2 \mathrm{H}$ and $4 \mathrm{H}$ hexagonal polytypes in Ag nanorods, and Leite et al. [59] reported the formation of a HCP structure from stacking faults in FCC crystals at a high temperature of synthesis using sodium borohydride as a reductive agent [58,59].

The lattice parameter contractions (Equation 1) obtained from interplanar distances were in the range of $-1.97 \%$ to $-1.39 \%$, compared to the JCPDS- 411402 value $(a=2.88 \mathrm{~A}$ ). Similarly, Figure 3C,D show an example of a nanoparticle with FCC structure found in the same sample. The lattice contraction has an average of $-0.83 \%$, which was less than those found in $4 \mathrm{H}$ nanoparticles. The lattice contraction of pure silver nanoparticles with FCC structure has been predicted by theoretical calculations, and confirmed by experimental data; the lattice contraction found in the present study was similar to those predicted for Ag nanoparticles smaller than $20 \mathrm{~nm}(-0.8 \%)$ [60-63]. However, further analysis should be carried out to study the possible correlation between the type of structure and lattice expansion in the inhibitory activity of Ag. 


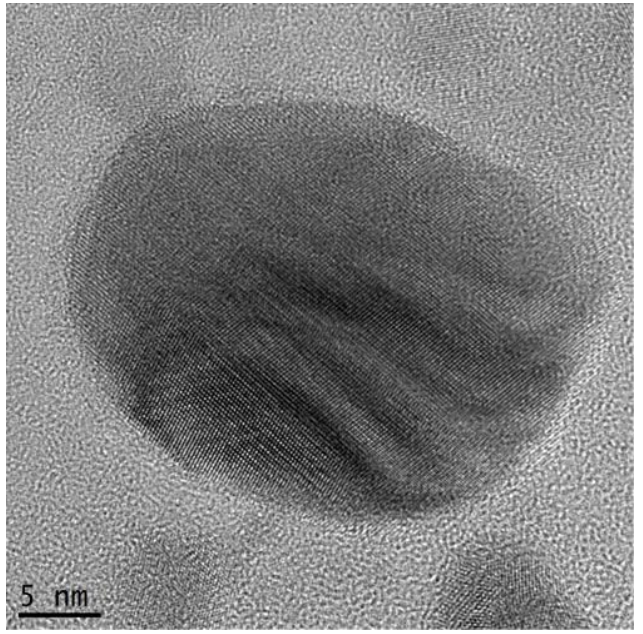

(A)

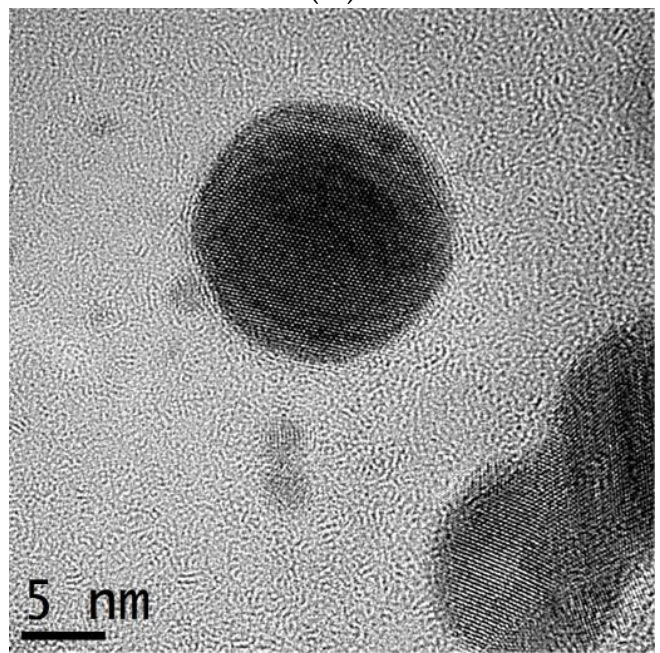

(C)

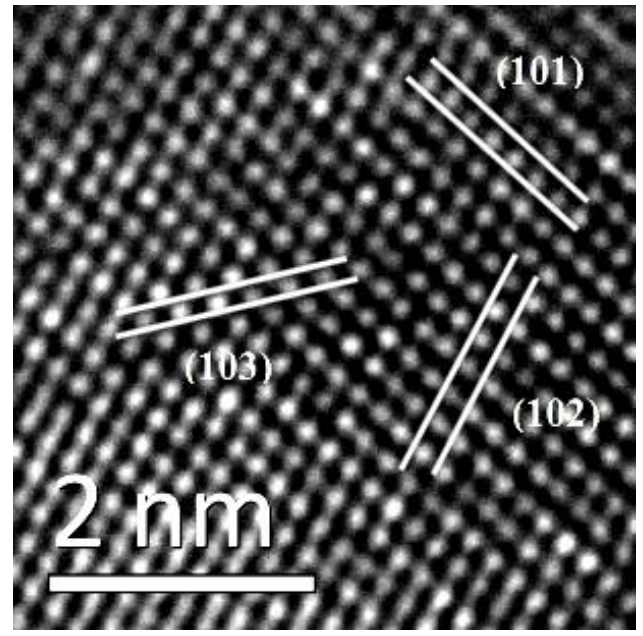

(B)

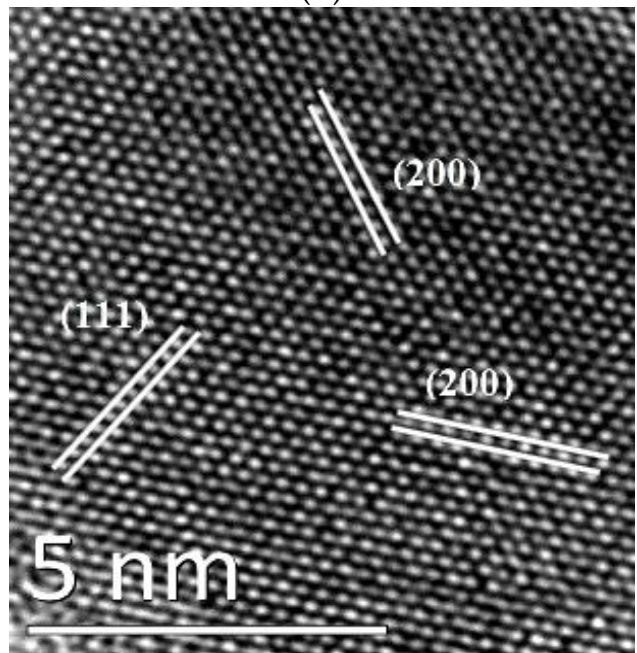

(D)

Figure 3. Representative HR-TEM micrographs of AgNPs taken at (A) Focus of a nanoparticle with an approximate diameter of $25 \mathrm{~nm},(\mathbf{B})$ The interplanar spaces found from the electron diffraction pattern correspond to a compact hexagonal structure. (C) Focus of a nanoparticle with an approximate diameter of $17 \mathrm{~nm}$. (D) Nanoparticle with face centered cubic structure.

XPS analysis was carried out to study the composition and oxidation state of Ag nanoparticles. A survey scan showed the presence of different elements such as $\mathrm{Ag}, \mathrm{O}, \mathrm{C}, \mathrm{N}, \mathrm{K}, \mathrm{S}, \mathrm{Cl}, \mathrm{Mg}$ and $\mathrm{Na}$. Further detailed scans were performed to calculate the following concentration of each element in weight percent: $41.8 \%, 25.6 \%, 21.7 \%, 6.7 \%, 2.3 \%, 0.9 \%, 0.5 \%, 0.4 \%$ and $0.2 \%$ (in the same sequence). The absence of a cleaning process resulted in high content of elements different than Ag in the sample. Additionally, the deconvolution of detailed scans in the Ag3d region showed the presence of two oxidation states for the silver. Green peaks located at 373.8 and $367.8 \mathrm{eV}$ correspond to the $\mathrm{Ag}^{+1}$ component $\left(3 \mathrm{~d}_{3 / 2}\right.$ and $\left.3 \mathrm{~d}_{3 / 2}\right)$, whereas blue signals sited at 374.3 and $368.3 \mathrm{eV}$ belong to $3 \mathrm{~d}_{3 / 2}$ and $3 \mathrm{~d}_{3 / 2}$ photoemissions of metallic silver, $\mathrm{Ag}^{0}$ (Figure 4). The binding energies agreed with previous XPS reports [62]. $\mathrm{Ag}^{0}$ and $\mathrm{Ag}^{+1}$ proportion results were very similar (51\% and 49\%, respectively). This result confirmed that synthesis parameters were not sufficient to completely reduce the silver from $\mathrm{AgNO}_{3}$ precursor. Considering that $\mathrm{XRD}$ diffractions for $\mathrm{AgNO}_{3}$ and $\mathrm{Ag}_{2} \mathrm{O}$ were very weak and the XPS concentration of $\mathrm{Ag}^{+1}$ species was high, it was concluded that part of silver from the precursor simply crystallized as a non-identified organometallic compound from geranium (see un-identified peaks with higher intensity at $2 \theta=31$ and $26.5^{\circ}$ ). 


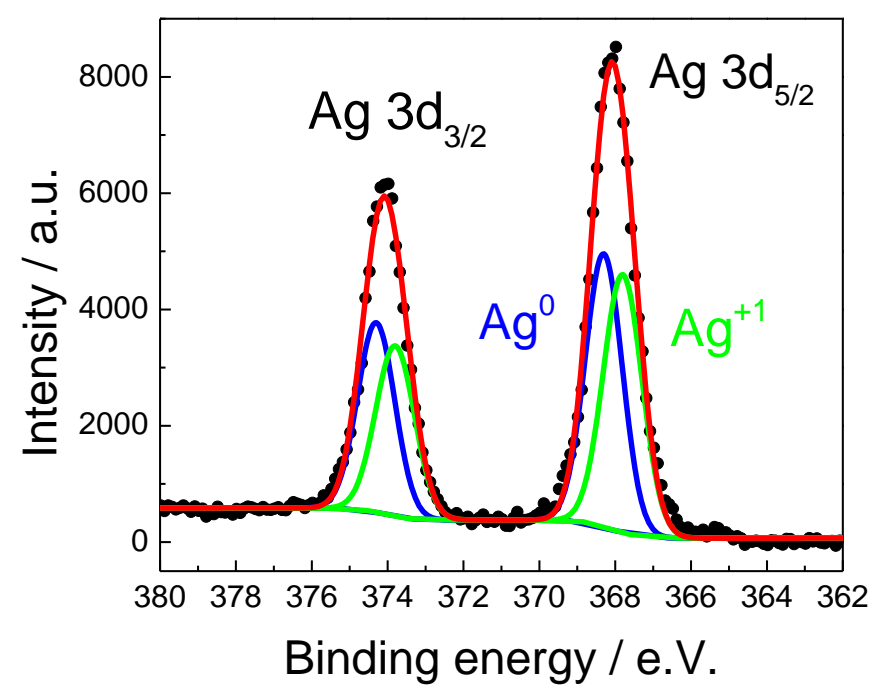

Figure 4. Detailed Spectra of the Ag3d region for the Ag nanoparticles synthesized with Geranium. Black points are experimental data and the red line is the fitting result.

For the analysis of antibacterial activity, $P$. aeruginosa was incubated until reaching turbidity of 0.5 (McFarland scale) corresponding to a concentration of $1.5 \times 10^{8} \mathrm{CFU} / \mathrm{mL}$ (Table 1) [64].

Table 1. Composition and cellular concentration according to the different turbidity patterns of the McFarland scale.

\begin{tabular}{ccc}
\hline McFarland Number & $\begin{array}{c}\text { Approximate Cell Number } \\
\text { in Suspension [CFU */mL] }\end{array}$ & $\begin{array}{c}\text { Approximate Cell Number } \\
\text { in Biofilm [CFU */mL] }\end{array}$ \\
\hline 0.5 & $1.5 \times 10^{8}$ & $5.0 \times 10^{6}$ \\
1.0 & $3.0 \times 10^{8}$ & $1.0 \times 10^{7}$ \\
2.0 & $6.0 \times 10^{8}$ & $2.0 \times 10^{7}$ \\
3.0 & $9.0 \times 10^{8}$ & $3.0 \times 10^{7}$ \\
\hline
\end{tabular}

* CFU: colony-forming unit.

Tests were performed using nanoparticle concentrations of $0.36,0.18,0.09,0.05$ and $0.02 \mu \mathrm{g} / \mathrm{mL}$. As shown in Figure 5, P. aeruginosa has a short latency phase and an exponential phase with a duration of $8 \mathrm{~h}[65,66]$; therefore, contact times of 0,2 and $4 \mathrm{~h}$ were determined to ensure the culture was within the exponential phase.

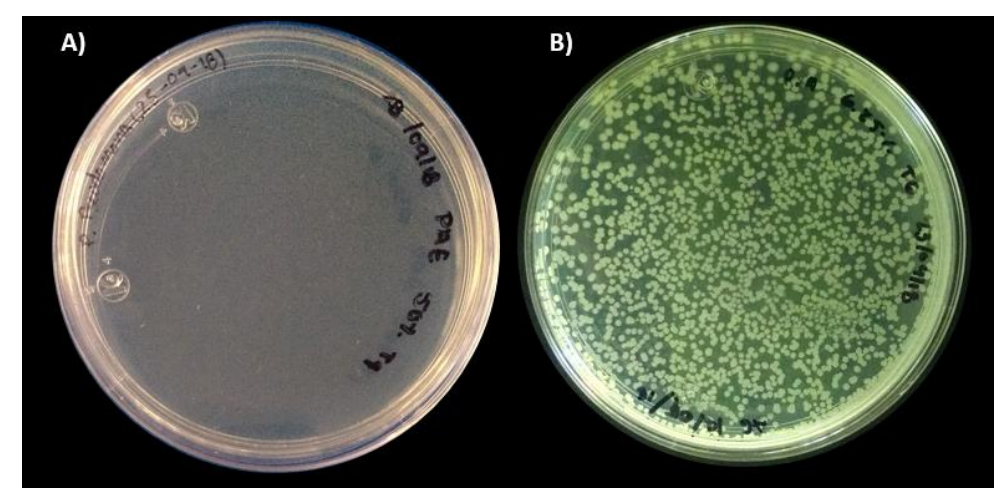

Figure 5. P. aeruginosa (ATCC 27853) cultures cultivated with silver nanoparticles at concentrations of (A) $0.72 \mu \mathrm{g} / \mathrm{mL}$ and (B) $0.02 \mu \mathrm{g} / \mathrm{mL}$ after $4 \mathrm{~h}$. 
Figure 5 shows the plates for limit concentrations; for $0.02 \mu \mathrm{g} / \mathrm{mL}$ it is possible to observe abundant growth of colonies, while for the concentration $0.72 \mu \mathrm{g} / \mathrm{mL}$ there is near-zero growth.

Subsequently, P. aeruginosa was incubated in nutrient broth at $35{ }^{\circ} \mathrm{C}$ with constant agitation promoting contact with the AgNPs. The colony-forming units (CFU) were counted on nutritive agar plates for each sample; the plates were allowed to incubate for $24 \mathrm{~h}$ at $35^{\circ} \mathrm{C}$. Figure 6 and Table 2 show, quantitatively and qualitatively, the variation of the growth of colonies according to the concentration of nanoparticles and incubation time. The highest concentration corresponds to $0.36 \mu \mathrm{g} / \mathrm{mL}$, which does not present any growth at any incubation time, while for the concentration of $0.18 \mu \mathrm{g} / \mathrm{mL}$, inhibitory activity is observed after $2 \mathrm{~h}$. In the case of the lowest concentrations ( 0.09 and $0.05 \mu \mathrm{g} / \mathrm{mL})$, a slight decrease in the growth of colonies is observed, presenting as inhibitory at $4 \mathrm{~h}$.

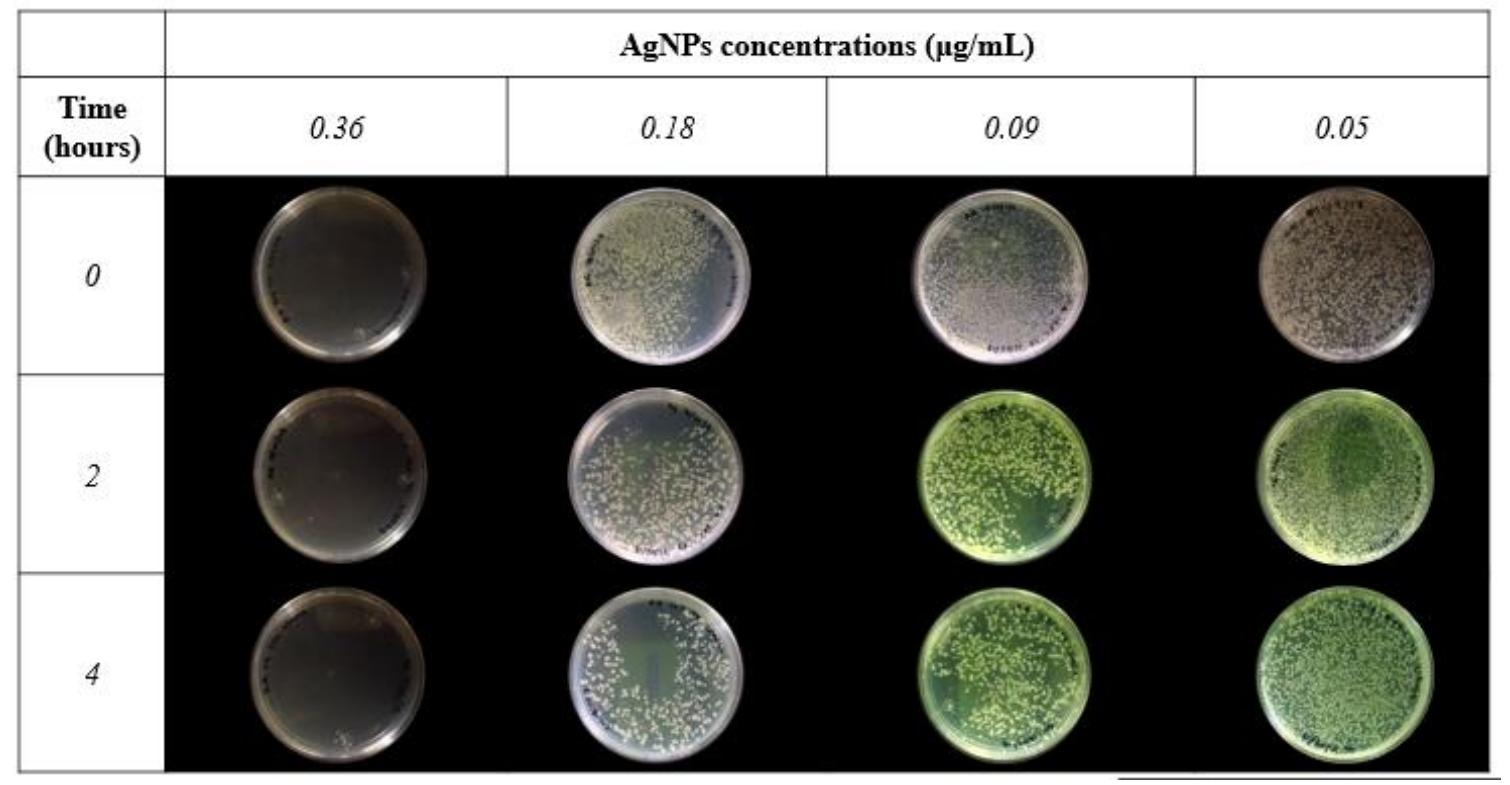

Figure 6. Matrix of P. aeruginosa cultures at different AgNP concentrations and incubation times.

Table 2. Average cell concentrations of P. aeruginosa at different AgNP concentrations and incubation times.

\begin{tabular}{cccc}
\hline \multirow{2}{*}{$\begin{array}{c}\text { AgNPs Concentration } \\
(\boldsymbol{\mu} \mathbf{g} / \mathbf{m L})\end{array}$} & \multicolumn{3}{c}{ Average Cell Concentration (CFU/mL) } \\
\cline { 2 - 4 } & $\mathbf{0 ~ h}$ & $\mathbf{2} \mathbf{~}$ & $\mathbf{4} \mathbf{~ h}$ \\
\hline 0.36 & 0 & 0 & 0 \\
0.18 & $300.7 \pm 168.8$ & $38.8 \pm 18.4$ & $16.8 \pm 18.0$ \\
0.09 & $1032.8 \pm 196.9$ & $403.0 \pm 282.7$ & $326.2 \pm 135.6$ \\
0.05 & $1500 \pm 0$ & $900 \pm 138.5$ & $705 \pm 26.3$ \\
\hline
\end{tabular}

Table 3 shows, in summary, the conditions used in cultures of P. aeruginosa with different sizes of AgNPs and the minimum inhibitory concentrations obtained. All experiments were always carried out under the same conditions. The minimum inhibitory concentration to eliminate bacteria depends mainly on the diameter and concentration stored by the nanoparticles in the colloidal solution.

Subsequently, a disk test was performed to analyze the antimicrobial activity of the AgNPs based on measurement of the inhibition zones, using concentrations of $0.72,0.36,0.18,0.09,0.05 \mu \mathrm{g} / \mathrm{mL}$ on Mueller-Hinton agar plates. Figure 7 shows the inhibition halos obtained; although the halos are not very evident, the decrease of these can be observed, as the concentration of AgNPs decreases. 
Table 3. Comparison of the inhibitory effects of AgNPs against P. aeruginosa cultures found by different authors.

\begin{tabular}{cccc}
\hline Reference & Conditions & Particle Size $(\mathbf{n m})$ & MIC $(\boldsymbol{\mu g} / \mathbf{m L})$ \\
\hline This work & $35^{\circ} \mathrm{C}, 4 \mathrm{~h}$ & $50 \pm 2.5$ & 0.18 \\
Olvera, et al. [67] & $37^{\circ} \mathrm{C}, 4 \mathrm{~h}$ & 10.32 & 10 \\
Olvera, et al. [67] & $37^{\circ} \mathrm{C}, 4 \mathrm{~h}$ & 9.53 & 5 \\
Flores, [68] & $35^{\circ} \mathrm{C}, 4 \mathrm{~h}$ & $6 \pm 2$ & 5.3 \\
Martinez, [69] & $35^{\circ} \mathrm{C}, 6 \mathrm{~h}$ & $24.4 \pm 9$ & 0.4 \\
\hline
\end{tabular}

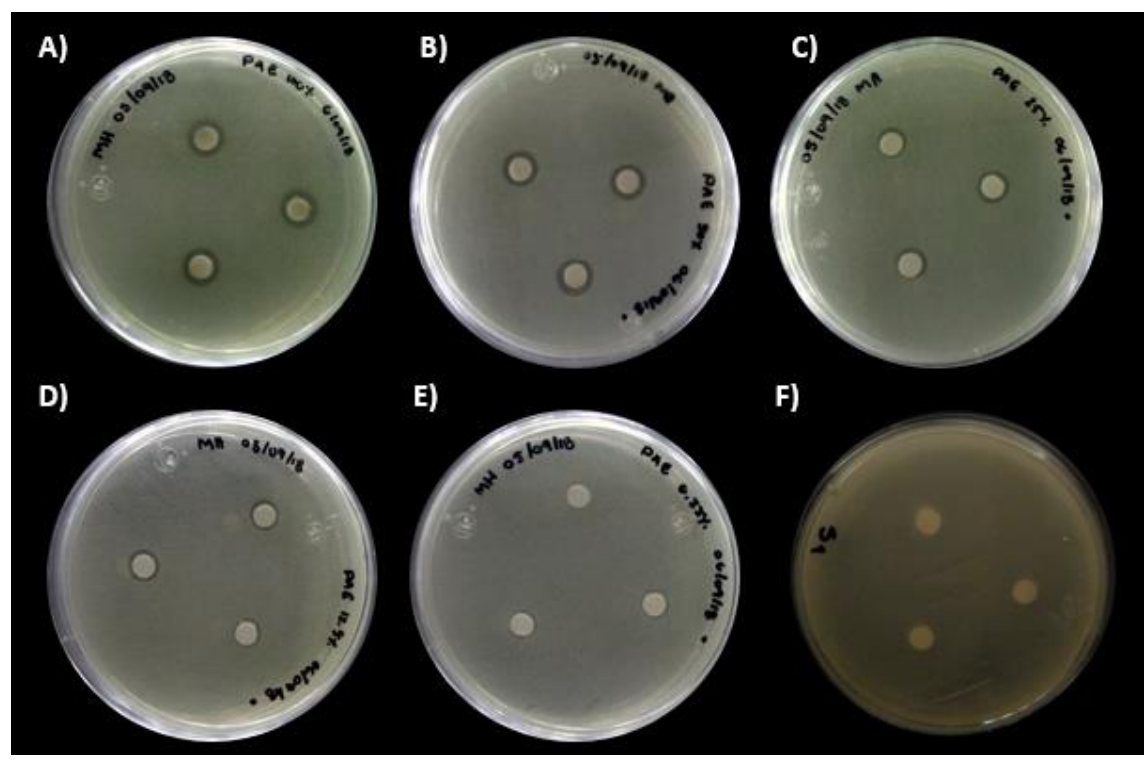

Figure 7. Inhibition halos of P. aeruginosa cultures at different AgNPs concentrations: (A) 0.72, (B) 0.36, (C) 0.18, (D) 0.09 and (E) $0.05 \mu \mathrm{g} / \mathrm{mL}$. (F) Control using distilled water.

Table 4 shows the average values of the inhibition halos; the largest halo is $1.08 \pm 0.2 \mathrm{~cm}$, obtained at the concentration of $0.72 \mu \mathrm{g} / \mathrm{mL}$; this value is close to $1.4 \pm 0.32 \mathrm{~cm}$ at a concentration of $31 \mu \mathrm{g} / \mathrm{mL}$ [65] after $24 \mathrm{~h}$. For the lowest concentrations, there is no significant variation between 0.09 and $0.05 \mu \mathrm{g} / \mathrm{mL}$.

Table 4. Halos of average inhibition in Pseudomonas aeruginosa cultures at different concentrations of AgNPs 0.72, 0.36, 0.18, 0.09, $0.05 \mu \mathrm{g} / \mathrm{mL}$.

\begin{tabular}{cc}
\hline AgNPs Concentration $(\boldsymbol{\mu g} / \mathrm{mL})$ & Average Inhibition Halos $(\mathrm{cm})$ \\
\hline 0.72 & $1.08 \pm 0.2$ \\
0.36 & $0.96 \pm 0.05$ \\
0.18 & $0.85 \pm 0.04$ \\
0.09 & $0.75 \pm 0.04$ \\
0.05 & $0.68 \pm 0.03$ \\
\hline
\end{tabular}

The mechanisms of action presented by the AgNPs against bacterial cultures depend on their size, shape, surface, surface charge, solubility, time of exposure and concentration. In studies on Pseudomonas aeruginosa cultures, it is due to the inhibition of several proteins present in the membrane related to the transport of ions, causing oxidative stress [70,71].

\section{Conclusions}

Silver nanoparticles were synthesized by a green method using Geranium extract as a reducing agent. The presence of AgNPs with a diameter between 15 and $50 \mathrm{~nm}$ was determined by UV-Vis measurements, HRTEM and TEM imaging. The antibacterial activity of AgNPs in solution against 
Pseudomonas aeruginosa (ATCC-27853) was determined with a minimum inhibitory AgNPs concentration of $0.36 \mu \mathrm{g} / \mathrm{mL}$ at $0 \mathrm{~h}$, while the concentration of $0.18 \mu \mathrm{g} / \mathrm{mL}$ presents a total inhibition of the bacterium after $2 \mathrm{~h}$. We suggest that AgNPs can be an optimal antibacterial alternative for biomedical applications. Future work can be on cytotoxicity analysis in living cells, using the minimum inhibitory AgNP concentrations or complex.

Author Contributions: Writing- original draft and supervision- J.C.M.E., R.C.C., M.A.R.M.; Writing-review and editing: all the authors. Synthesis and characterization of AgNPs, and antibacterial activity tests: R.A.S.C., J.H.M., M.A.R.M. and K.P.S.G. All authors have read and agreed to the published version of the manuscript.

Funding: Thanks to the Secretary of Research and Postgraduate Studies of the Instituto Politecnico Nacional for financial support through the projects number SIP-20190044 and SIP-20195769.

Acknowledgments: The authors thank the Secretary of Research and Postgraduate Studies of the Instituto Politecnico Nacional. We also thank Lourdes Palma Tirado from the Institute of Neurobiology of the Universidad Autonoma de Mexico for the micrographs analysis. The authors thank to CNMN-IPN for the technical support in the characterization.

Conflicts of Interest: The authors declare no conflict of interest.

\section{References}

1. Staggers, N.; Mckasky, T.; Braselton, N.; Kennedy, R. Nanotechnology: The coming revolution and its implications for consumers, clinicians, and informatics. Nurs. Outlook 2008, 56, 268-274. [CrossRef] [PubMed]

2. Hochella, M.F. Nanoscience and technology: The next revolution in the Earth sciences. Earth Planet. Sci. Lett. 2002, 203, 593-605. [CrossRef]

3. Beumer, K. Broadening nanotechnology's impact on development. Nat. Nanotechnol. 2016, 11, 398-400. [CrossRef] [PubMed]

4. Lieber, C.M.; Gao, R.; Strehle, S. Nanoscale Sensors for Intracellular and Other Applications. American Patent No. U.S. 9638717 B2, 2 May 2017.

5. Jiang, H.; Moon, K.; Zhang, Z.; Pothukuchi, S.; Wong, C.P. Variable frequency microwave synthesis of silver nanoparticles. J. Nanopart. Res. 2006, 8, 117-124. [CrossRef]

6. Laksee, S.; Puthong, S.; Teerawatananond, T.; Palaga, T.; Muangsin, N. Highly efficient and facile fabrication of monodispersed $\mathrm{Au}$ nanoparticles using pullulan and their application as anticancer drug carriers. Carbohydr. Polym. 2017, 173, 178-191. [CrossRef]

7. Parashar, U.K.; Saxena, S.P.; Srivastava, A. Bioinspired synthesis of silver nanoparticles. Dig. J. Nanomat. Biostruct. 2009, 4, 159-166.

8. Rashid, R.; Murtaza, G.; Zahra, A. Gold Nanoparticles: Synthesis and Applications in Drug. Trop. J. Pharm. Res. 2014, 13, 1169-1177.

9. Anand, K.; Tiloke, C.; Naidoo, P.; Chuturgoon, A.A. Phytonanotherapy for management of diabetes using green synthesis nanoparticles. J. Photochem. Photobiol. B 2017, 173, 626-639. [CrossRef]

10. Handy, R.D.; Henry, T.B.; Scown, T.M.; Johnston, B.D.; Tyler, C.R. Manufactured nanoparticles: Their uptake and effects on fish-a mechanistic analysis. Ecotoxicology 2008, 17, 396-409. [CrossRef]

11. Biswas, P.; Wu, C.Y. Critical review: Nanoparticles and the environment. J. Air Waste Manag. Assoc. 2005, 55, 708-746. [CrossRef]

12. Nowack, B.; Bucheli, T.D. Occurrence, behaviour and effects of nanoparticles in the environment. Environ. Pollut. 2007, 150, 5-22. [CrossRef] [PubMed]

13. Sajid, M.; Llyas, M.; Basheer, C. Impact of nanoparticles on human and environment: Review of toxicity factors, exposures, control strategies, and future prospects. Environ. Sci. Pollut. Res. Int. 2015, 22, 4122-4143. [CrossRef]

14. Sastry, M.; Ahmad, A.; Khan, M.I.; Kumar, R. Microbial Nanoparticle Production. Nanobiotechnology, Concepts, Applications and Perspectives; Niemeyer, C.M., Mirkin, C.A., Eds.; Wiley-VCH: Weinheim, Germany, 2004; pp. 126-135.

15. Bhattacharya, D.; Rajinder, G. Nanotechnology and potential of microorganisms. Crit. Rev. Biotechnol. 2005, 25, 199-204. [CrossRef]

16. Mohanpuria, P.; Rana, N.K.; Yadav, S.K. Biosynthesis of nanoparticles: Technological concepts and future applications. J. Nanopart. Res. 2008, 10, 507-517. [CrossRef] 
17. Tippayawat, P.; Phromviyo, N.; Boueroy, P. Green synthesis of silver nanoparticles in aloe vera plant extract prepared by a hydrothermal method and their synergistic antibacterial activity. PeerJ 2016, 19, e2589. [CrossRef] [PubMed]

18. Bagherzade, G.; Tavakoli, M.M.; Namaei, M.H. Green synthesis of silver nanoparticles using aqueous extract of saffron (Crocus sativus L.) wastages and its antibacterial activity against six bacteria. Asian Pac. J. Trop. Biomed. 2017, 7, 227-233. [CrossRef]

19. Gomathi, M.; Rajkumar, P.V.; Prakasam, A.; Ravichandran, K. Green synthesis of silver nanoparticles using Datura stramonium leaf extract and assessment of their antibacterial activity. Resour. Effic. Technol. 2017, 3, 280-284. [CrossRef]

20. Singh, A.; Mittal, S.; Shrivastav, R.; Dass, S.; Srivastava, J.N. Biosynthesis of silver nanoparticles using Ricinus communis L. Leaf extract and its antibacterial activity. Dig. J. Nanomater. Biostructures 2012, 7, 1157-1163.

21. Maqbool, Q.; Iftikhar, S.; Nazar, M. Green fabricated CuO nanobullets via Olea europaea leaf extract shows auspicious antimicrobial potential. IET Nanobiotechnol. 2017, 11, 463-468. [CrossRef]

22. Shende, S.; Ingle, A.P.; Gade, A.; Rai, M. Green synthesis of copper nanoparticles by Citrus medica Linn. (Idilimbu) juice and its antimicrobial activity. World J. Microbiol. Biotechnol. 2015, 31, 865-873. [CrossRef]

23. Ashraf, J.M.; Ansari, M.A.; Khan, H.M. Green synthesis of silver nanoparticles and characterization of their inhibitory effects on AGEs formation using biophysical techniques. Sci. Rep. 2016, 6, 20414. [CrossRef] [PubMed]

24. Shankar, S.; Ahmad, A.; Sastry, M. Geranium leaf assisted biosynthesis of silver nanoparticles. Biotechnol. Prog. 2003, 19, 1627-1631. [CrossRef] [PubMed]

25. Gaffet, E.; Tachikart, M.; El Kedim, O.; Rahouadj, R. Nanostructural materials formation by mechanical alloying: Morphologic analysis based on transmission and scanning electron microscopic observations. Mater. Charact. 1996, 36, 185-190. [CrossRef]

26. Amulyavichus, A.; Daugvila, A.; Davidonis, R.; Sipavichus, C. Study of chemical composition of nanostructural materials prepared by laser cutting of metals. Fizika Met. Met. 1998, 85, 111-117.

27. Thirumalai, V.A.; Prabhu, D.; Soniya, M. Stable silver nanoparticle synthesizing methods and its applications. J. Biol. Sci. Res. 2010, 1, 259-270.

28. Zhu, J.; Liao, X.; Chen, H.Y. Electrochemical preparation of silver dendrites in the presence of DNA. Mater. Res. Bull. 2001, 36, 1687-1692. [CrossRef]

29. Salkar, R.A.; Jeevanandam, P.; Aruna, S.T.; Koltypin, Y.; Gedanken, A. The sonochemical preparation of amorphous silver nanoparticles. J. Mater. Chem. 1999, 9, 1333-1335. [CrossRef]

30. Mandal, S.; Arumugam, S.; Pasricha, R.; Sastry, M. Silver nanoparticles of variable morphology synthesized in aqueous foams as novel templates. Bull. Mater. Sci. 2001, 28, 503-510. [CrossRef]

31. Rolim, W.R.; Pelegrino, M.T.; de Araújo Lima, B.; Ferraz, L.S.; Costa, F.N.; Bernardes, J.S.; Rodigues, T.; Brochi, M.; Seabra, A.B. Green tea extract mediated biogenic synthesis of silver nanoparticles: Characterization, cytotoxicity evaluation and antibacterial activity. Appl. Surf. Sci. 2019, 463, 66-74. [CrossRef]

32. Scherer, M.D.; Sposito, J.C.; Falco, W.F.; Grisolia, A.B.; Andrade, L.H.; Lima, S.M.; Machado, G.; Nascimento, V.A.; Daniel, A.G.; Heberton, W.; et al. Cytotoxic and genotoxic effects of silver nanoparticles on meristematic cells of Allium cepa roots: A close analysis of particle size dependence. Sci. Total Environ. 2019, 660, 459-467. [CrossRef]

33. Geetha, R.; Ashokkumar, T.; Tamilselvan, S. Green synthesis of gold nanoparticles and their anticancer activity. Cancer Nano 2013, 4, 91-98. [CrossRef] [PubMed]

34. Rozalen, M.; Sánchez, M.; Fernández, M.; Widmann, T.J.; Rivera, J. Synthesis of controlled-size silver nanoparticles for the administration of methotrexate drug and its activity in colon and lung cancer cells. RSC Adv. 2020, 10, 10646-10660. [CrossRef]

35. Gomathi, A.C.; Rajarathinam, S.X.; Sadiq, A.M.; Rajeshkumar, S. Anticancer activity of silver nanoparticles synthesized using aqueous fruit shell extract of Tamarindus indica on MCF-7 human breast cancer cell line. J. Drug Deliv. Sci. Technol. 2020, 55, 101376. [CrossRef]

36. Salem, W.; Leitner, D.R.; Zingl, F.G. Antibacterial activity of silver and zinc nanoparticles against Vibrio cholerae and enterotoxic Escherichia coli. Int. J. Med. Microbiol. 2015, 305, 85-95. [CrossRef]

37. Wang, L.; Hu, C. The antimicrobial activity of nanoparticles: Present situation and prospects for the future. Int. J. Nanomed. 2013, 12, 1227-1249. [CrossRef] 
38. Elumalai, K.; Velmurugan, S. Green synthesis, characterization and antimicrobial activities of Zinc Oxide nanoparticles from the leaf extract of Azadirachta indica (L.). Appl. Surf. Sci. 2015, 345, 329-336. [CrossRef]

39. Cardeño, L.; Londoño, M.E. Síntesis verde de nanopartículas de plata mediante el uso del ajo (Allium sativum). Revista Soluciones de Postgrado EIA 2014, 12, 129-140.

40. Ledezma, A.; Romero, J.; Hernández, M.; Moggio, I.; Arias, E.; Padrón, G. Síntesis biomimética de nanopartículas de plata utilizando extracto acuoso de nopal (Opuntia sp.) y su electrohilado polimérico. Superficies y Vacío 2014, 27, 133-140.

41. Sulaiman, G.M.; Mohammed, W.H.; Marzoog, T.R.; Al-Amiery, A.A.A.; Kadhum, A.A.H.; Mohamad, A.B. Green synthesis, antimicrobial and cytotoxic effects of silver nanoparticles using Eucalyptus chapmaniana leaves extract. Asian Pac. J. Trop. Biomed. 2013, 3, 58-63. [CrossRef]

42. Haytham, M.M.I. Green synthesis and characterization of silver nanoparticles using banana peel extract and their antimicrobial activity against representative microorganisms. J. Radiat. Res. Appl. Sci. 2015, 8, $265-275$.

43. Mittal, A.; Chisti, Y.; Banerjee, U. Synthesis of metallic nanoparticles using plant extracts. Biotechnol. Adv. 2013, 31, 346-356. [CrossRef] [PubMed]

44. Fayaz, A.; Balaji, K.; Girilal, M. Biogenic synthesis of silver nanoparticles and their synergistic effect with antibiotics: A study against gram-positive and gram-negative bacteria. Nanomed. Nanotechnol. Biol. Med. 2010, 6, 103-109. [CrossRef] [PubMed]

45. Martínez, J.C.; Chequer, N.A.; González, J.L.; Cordova, T. Alternative methodology for gold nanoparticles diameter characterization using PCA technique and UV-VIS spectrophotometry. Nanosci. Nanotechnol. 2012, 2, 184-189. [CrossRef]

46. Smitha, S.L.; Nissamudeen, K.M.; Philip, D.; Gopchandran, K.G. Studies on surface plasmon resonance and photoluminescence of silver nanoparticles. Spectrochim. Acta Part A Mol. Biomol. Spectrosc. 2008, 71, 186-190. [CrossRef]

47. Amanchy, R. Phytofabrication of silver nanoparticles using Myriostachya wightiana as a novel bioresource, and evaluation of their biological activities. Braz. Arch. Biol. Technol. 2017, 60. [CrossRef]

48. Creighton, J.; Blatchford, C.; Albrecht, M. Plasma resonance enhancement of Raman scattering by pyridine adsorbed on silver or gold sol particles of size comparable to the excitation wavelength. J. Chem. Soc. Faraday Trans. II 1979, 75, 790-798. [CrossRef]

49. Patakfalvi, R.; Oszko, A.; Dekany, I. Synthesis and characterization of silver nanoparticle/kaolinite composites. Colloids Surf. A Physicochem. Eng. Asp. 2013, 220, 45-54. [CrossRef]

50. Elizondo, N.; Segovia, P.; Coello, V.; Torres, E. Green Synthesis and Characterizations of Silver and Gold Nanoparticles. In Green Chemistry-Environmentally Benign Approaches; Kidwai, M., Ed.; Intech: Rijeka, Croatia, 2012; pp. 139-156.

51. Green, D.; Jayasundara, S.; Lam, Y.; Harris, M. Chemical reaction kinetics leading to the first Stober silica nanoparticles-NMR and SAXS investigation. J. Non-Cryst. Solids 2003, 315, 166-179. [CrossRef]

52. Khan, M.; Khan, M.; Adil, S. Green synthesis of silver nanoparticles mediated by Pulicaria glutinosa extract. Int. J. Nanomed. 2013, 8, 1507-1516.

53. Chhatre, A.; Solasa, P.; Sakle, S.; Thaokar, R.; Mehra, A. Color and surface plasmon effects in nanoparticle systems: Case of silver nanoparticles prepared by microemulsion route. Colloids Surf. A Physicochem. Eng. Asp. 2012, 404, 83-92. [CrossRef]

54. Annamalai, J.; Nallamuthu, T. Green synthesis of silver nanoparticles: Characterization and determination of antibacterial potency. Appl. Nanosci. 2016, 6, 259-265. [CrossRef] [PubMed]

55. Abdel-Fattah, W.I.; Abdelsattar, A.; Nagwa, A.; Salama, E.; Maghraby, A.; Ghareib, W. Functionality, antibacterial efficiency and biocompatibility of nanosilver/chitosan/silk/phosphate scaffolds 1 . Synthesis and optimization of nanosilver/chitosan matrices through gamma rays irradiation and their antibacterial activity. Mater. Res. Express 2014, 1, 035024. [CrossRef]

56. Diantoro, M.; Fitrianingsih, R.; Mufti, N.; Fuad, A. Synthesis of silver nanoparticles by chemical reduction at various fraction of MSA and their structure characterization. AIP Conf. Proc. 2014, 257, 1589.

57. Virgen-Ortiz, A.; Limón-Miranda, S.; Soto-Covarrubias, M.; Apolinar-Iribe, A.; Rodríguez-León, E.; Iñiguez-Palomares, R. Biocompatible silver nanoparticles synthesized using rumex hymenosepalus extract decreases fasting glucose levels in diabetic rats. Dig. J. Nanomater. Biostruc. 2015, 10, 927-933. 
58. Chakraborty, I.; Carvalho, D.; Shirodkar, S.N.; Lahiri, S.; Bhattacharyya, S.; Banerjee, R.; Waghmare, U.; Ayyub, P. Novel hexagonal polytypes of silver: Growth, characterization and first-principles calculations. J. Phys. Condens. Matter 2011, 23, 325401. [CrossRef]

59. Leite, M.S.; Rodrigues, V.; Zanchet, D. Structural effects on Au and Ag colloidal nanoparticles. Progr. Colloid Polym. Sci. 2004, 128, 131-134.

60. Sadaiyandi, K. Size dependent Debye temperature and mean square displacements of nanocrystalline Au, Ag and Al. Mater. Chem. Phys. 2009, 115, 703-706. [CrossRef]

61. Prasad, P.S.; Bilal, A.S. Structural Studies of Silver Nanoparticles Obtained Through Single-Step Green Synthesis. IOP Conf. Ser. Mater. Sci. Eng. 2015, 92, 012004.

62. Qi, W.H.; Wang, M.P. Size and shape dependent lattice parameters of metallic nanoparticles. J. Nanoparticle Res. 2005, 7, 51-57. [CrossRef]

63. Cui, D.H.; Zheng, Y.F.; Song, X.C. A novel visible-light-driven photocatalyst $\mathrm{Ag}_{2} \mathrm{O} / \mathrm{AgI}$ with highly enhanced photocatalytic performances. J. Alloys Compd. 2017, 701, 163-169. [CrossRef]

64. McFarland, J. Nephelometer: An instrument for media used for estimating the number of bacteria in suspensions used for calculating the opsonic index and for vaccines. J. Am. Med. Assoc. 1907, 14, 1176-1178. [CrossRef]

65. Huang, Z.; Hu, Y.; Shou, S.; Song, M. Isolation and partial characterization of cyclic lipopeptide antibiotics produced by Paenibacillus ehimensis B7. BMC Microbiol. 2013, 13, 87. [CrossRef] [PubMed]

66. Sethuraman, P.; Balasubramanian, N. Removal of $\mathrm{Cr}(\mathrm{VI})$ from aqueous solution using Bacillus subtilis, Pseudomonas aeruginosa and Enterobacter cloacae. Int. J. Eng. Sci. Technol. 2010, 2, 1811-1825.

67. Olvera, C.; Alexandra, D. Evaluación del Efecto Antimicrobiano de las Nanopartículas de Plata Sintetizadas por Paecilomyces variotii. Master's Thesis, Instituto Politécnico Nacional, Mexico City, Mexico, 2017.

68. Flores, C.Y. Nanopartículas de Plata con Potenciales Aplicaciones en Materiales Implantables: Síntesis, Caracterización Fisicoquímica y Actividad Bactericida. Ph.D. Thesis, Instituto de Investigaciones Fisicoquímicas Teóricas y Aplicadas, Univesidad Nacional de la Plata, La Plata, Argentina, 2014.

69. Martínez, F. Evaluación de la Toxicidad de Nanopartículas de Plata y Dióxido de Titanio en Procariotas y Eucariotas. Ph.D. Thesis, Energías Renovables y Protección del Medio Ambiente, CIMAV, Chihuahua, Mexico, 2015.

70. Saba, H. A Review on Nanoparticles: Their Synthesis and Types. Res. J. Recent. Sci. 2015, 4, 1-3.

71. Yan, X.; Bin, H.; Lihong, L. Antibacterial mechanism of silver nanoparticles in Pseudomonas aeruginosa: Proteomics approach. Metallomics 2018, 10, 557-564. [CrossRef] 